T

\title{
Interactive Learning Multimedia Development Using Articulate Storyline 2 on Plant Breeding Course in State Vocational School Loa Janan, East Kalimantan, Indonesia
}

\author{
Zaenab Hanim ${ }^{1}$, Rahma Diana ${ }^{2}$, Rahmat Soe'oed ${ }^{3}$, Sulfikar Sallu $^{4}$ \\ ${ }^{1,3}$ Educatioanal Management, Universitas Mulawarman, East Kalimantan, Indonesia \\ ${ }^{2}$ Selyca Islamic School Samarinda, East Kalimantan Indonesia \\ ${ }^{3}$ Faculty of Information Technology, Universitas Sembilan belas November Kolaka, Southeast Sulawesi, Indonesia \\ 1'zaenab.hanim@fkipunmul.ac.id, ${ }^{2}$ amachdyana@gmail.com, ${ }^{3}$ machdyana@gmail.com, ${ }^{4}$ sulfikar.sallu@gmail.com
}

\begin{abstract}
The research aims to find out the feasibility and effectiveness of using interactive multimedia using articulate storyline 2 on plant breeding course. It was conducted at State Vocational Senior High School (SMK Negeri 1) Loa Janan, East Kalimantan, Indonesia. It is developmentbased research which is a process used to develop and validate educational products using interactive multimedia Articulate Storyline 2 with the following respondents: multimedia experts, school teachers and all students of grade X of the school. Interviews were conducted with the school principal, media expert of Information Technology (IT), the teacher of plant breeding course and 4 students of the grade X, while the data were descriptively analyzed. The results of the research indicated that the feasibility of the research development was categorized very good or very feasible and its effectiveness has increased even exceeded the school completeness standard of 75.
\end{abstract}

Keywords

Interactive Multimedia; Articulate Storyline 2; Plant Breeding

Article Received: 10 August 2020, Revised: 25 October 2020, Accepted: 18 November 2020

\section{Introduction}

In education, computers can be used as a tool or media in the teaching and learning process, both for teachers and students. They have a lot of functions such as educational technology application, media tutorial, teaching aids, and test equipment. Each of these functions has both advantages and disadvantages. Many problems of developing education require the use of technology, Information and communication technology (ICT) in particular. Referring to Dwi Priyono (2006), ICT application in the education field to cope with the learning problems requires several requirements, for examples big expenses for ICT investment and skilful human resources in managing and developing education.

Computers as a learning medium have advantages in learning interaction, foster students' interest in independent learning, and can be adjusted to the students' needs. However, computer interaction with humans cannot replace interaction among humans (Muharlisiani et al., 2019). As test equipment, they have some advantages such as objectivity, accuracy, and speed in the calculation. However, they still have weaknesses in terms of morals and ethics. It was also found that students' willingness to learn independently is still low (Chen et al., 2011; Farrukh, Butt, \& Mansori, 2015; Umanailo, 2020a).

Before introducing the computers to students, parents and teachers should be able to understand the development of students' understanding of learning technologies that currently have applications in the form of utilizing communication and information technology (ICT) processes and products (Apriyanto \& Umanailo, 2019; Kimin, Rahman, Conang, \& Umanailo, 2020; Salampessy, Tuhelelu, Wahyudi, \& Umanailo, 2020). The technology in education is commonly used to solve educational and learning problems (Adiatma, 2014; Muhasidah et al., 2019; Rumaolat, Dusra, et al., 2019; Rumaolat, Lihi, Hamka, \& Umanailo, 2019; Zhao \& Hannum, 2019).

In order o improve the quality of learning, students need to be introduced to computers, to implement the application of edutainment programs (software), a combination of education and entertainment. Some weaknesses in improving the quality of learning are lack of human resources who can skillfully apply and operate technology in education, neither utilize nor develop ICT in education (Suartama, 2010). In addition to software programs, the internet world is increasingly meaningful to the students who enable the processing of knowledge or information from the sites they visit without limitation of distance and time (Tahir \& Umanailo, 2019; Umanailo, Yulisvestra, Oki, Mulyasari, \& Ridwan, 2019). In the next educational development, interactive online conference technology needs to be implemented and developed in the organization of education through all parts of Indonesia for the efficiency of time, the number of teaching staff, and classroom capacity.

The development of ICT has globally influenced and been implemented in almost all aspects of human life. All types of equipment resulting from technological innovations are the results of ICT utilization. Skills in utilizing ICT are essential for solving some of the human problems today, managing human resources, and working together in teams or groups. In the 21 st century, it is increasingly developing and also intervening in the organization of education, both in management and in the interactive learning process. Unfortunately, the teachers' and students' skills of using ICT as a learning multimedia in Indonesia has reached 30\% only (Rachman, Hamiru, Umanailo, Yulismayanti, \& 


\section{I}

Harziko, 2019; Romlah et al., 2020). Therefore, the teachers are required to understand the use of ICT to design learning that can improve the quality of education. The improvement was made by designing student learning activities and independence, namely interacting with technology as a learning medium (Huda, Haron, Ripin, Hehsan, \& Yaacob, 2017).

The development of ICT brought about a lot of changes in education, employment, and competencies needed by any kind of work field. Therefore, educators need to have several competencies, general and specific ones, such as critical thinking competencies, ICT competencies that enable someone to work, making decisions, handling dynamic and changing situations, and team or collaborative working and effective communication.

Educational institutions immediately begin the use of ICT as a cutting edge learning base, capture, and transfer the speed of transformation of knowledge to students (Ellen Costello et al, 2015 (Malmia et al., 2019; Mangesa et al., 2019; Nawawi et al., 2020). In a more specific context, education delivery policies, both those organized by the government and the community must be able to provide the students with broader access to understanding and mastery of the latest technology.

ICT-based education development provides at least two benefits (Rahmat, Gs, Djafri, Shofwan, \& Umanailo, 2019; Umanailo, 2020b; Yuli Kwartolo, 2010), firstly, ICT as an impetus for the education community including teachers to be more appreciative and proactive in maximizing educational potential; secondly, it provides broad opportunities for students to exploit every existing potential. The potential can be obtained from limited resources to facilitate collaboration between educators and students and information sharing. The development of ICT through the internet world, enables the development of better and faster information services in an educational institution, both within the college and school environment (Bodolica \& Spraggon, 2008; Xu, Polley, Hofmockel, \& Wilsey, 2017). The use of the internet in schools is limited to additional facilities, not yet becoming the main content in the curriculum taught to students. However, prospects, the use of ICT in schools is increasing rapidly, such as internet site services that present the activities of the education system in Indonesia, which summarizes information about the development of education in a communication network for school administrators, educators and other interested people. The role of the teacher to educate students who always keep abreast of the times in the use of the latest ICT without leaving culture is no longer an obstacle to developing innovation and creativity in the learning process.

The development of science and technology is familiar to teachers, but they do not fully understand their use and utilization in the learning process and evaluation with which they can increase the effectiveness and efficiency of learning. In a more specific context, to facilitate the learning process in the classroom, teachers need to use multimedia learning based on Articulate Storyline 2 for plant breeding subject in the State Vocational School (Hoang, Gautret, Memish, \& Al-Tawfiq, 2020). With this instructional media, the students are expected to be able to improve their low learning outcomes, which so far have been strongly assumed to be due to using the method of lecturing without media
(Zumla, Azhar, Alqahtani, Shafi, \& Memish, 2020). The use of this instructional media needs to consider several aspects based on the needs of its use to help students achieve the learning goals.

Articulate Storyline 2 is a software that can support the implementation of instructional media that can be used with conversation and discussion as well as input learning materials in various formats. Therefore, the presented materials can be more interesting and easier to understand because the information presented is not only in the form of writing but also in the form of images, videos, animations and other various formats. In making an instructional media, the characteristics of the material need to be considered because it can make the learning process effective and useful (Kirk, Emerson and Nabatchi, 2015; Silverberg, Tierney, \& Bodek, 2014; Siswanto, Supriyanto, Ni'mah, Asnawi, \& Wekke, 2019). While plant breeding lessons are characteristic of natural science material that is packaged in the form of the direct student experience so that it can be additional power to search, save, and apply the concepts he has already learned. The topics taught in the plant breeding course may foster and create positive attitudes of the students while the instructional media based on the articulate storyline 2 is expected to be presented as a source of learning to support the learning process either in class or independent learning.

Learning changes in plant breeding course using ICT with applications of Articulate Storyline 2 can improve students' academic abilities. Therefore, the researchers conducted the study into a research development of Articulate Storyline 2 as a learning medium of plant breeding course at the state vocational school because it can enhance an effective and efficient learning process and the use of the media can increase the students' motivation, understanding, and mastery of learning

\section{Literature Review}

The Association for Educational Communications and Technology (AECT) defines educational technology as an audio-visual communication. This definition has encouraged efforts to improve the quality of learning because the purpose of using each method and medium of communication is to help the learners fully develop their potential. According to AECT (1994), educational technology is a theory and practice in the design, development, utilization, management, and evaluation of a learning process and resources. However, in 2004 the definition was revised as follows "Educational Technology is the study and ethical practice of facilitating learning and improving performances by creating, using, and managing appropriate technological processes and resources". In the latest definition, the notion of ethics has been included because criticism directed at the 1994 definition of Educational Technology is the loss of humanity or ethics in its domain. The redefinition carried out by AECT in June 2004 has been socialized to all people related to education through social media such as the internet. 
T

\section{Interactive Learning Multimedia}

Unlike ordinary media, multimedia is a combination of various aspects such as text, graphics, sound, animation, and video that can only be delivered by using a computer or other electronic device. It also refers to various combinations of two or more media formats integrated into the form of information or program instructions. The interactive multimedia is a media equipped with a controller that can be operated by the users so that they can choose according to what they want for the next process. It is widely developed and utilized as a media for presentations, games, interactive CDs, and interactive quizzes. Broadly speaking, interactive instructional media is grouped into two groups, traditional and the latest technological media. The latest technological media includes (1) telecommunicationsbased media, such as teleconferences and distance lectures, and (2) microprocessor-based media, such as computerassisted instruction (CAI), computer games, intelligent tutoring systems, interactive, hypermedia, and compact (video) discs.

The interactive instructional media is also a teaching system that presents a combination of various teaching media such as video recording with computer control. Students not only see and hear the sound of the video but also provide active responses so that the speed and sequence of the presentation can be determined. It can be classified as e-learning teaching material which can be interpreted as learning using electronic and digital media. E-instructional media can be divided into two, online and offline interactive media (M. Jannah, Widohardhono, Fatimah, Dewi, \& Umanailo, 2019; Miftakhul Jannah, Widohardhono, Fatimah, Dewi, \& Umanailo, 2019; Malmia et al., 2019). A chosen, developed and appropriately used, instructional multimedia can provide enormous benefits for teachers and students.

Besides, it has several important advantages especially for the teachers and students as well in the learning process. Of the advantages are to enlarge very small and invisible objects to the eye such as germs, bacteria, electrons and so on; to minimize very large objects which are not possible to attend to schools, such as elephants, houses, mountains, etc.; to present complex objects such as the human body system, the operation of a machine and others; to present distant objects or events such as the moon, stars, snow, etc.; to present dangerous objects or events such as volcanic eruptions, tigers, poisons, etc.; and to increase student attractiveness and attention. The characteristics of instructional multimedia are as follows: (1) having more than one converging media, for example combining audio and visual elements; (2). being interactive in the sense of having the ability to accommodate user responses, and (3) being independent in the sense of providing convenience and completeness of the content so that users can use it without the guidance of others. While the format of multimedia learning presentations can be categorized into five groups such as 1) tutorial, 2) drills 3) simulations 4) experiments and 5) games.

\section{Effectiveness of Learning}

Hoy and Miskel explained that effectiveness is a very important concept because it can provide a picture of one's success in achieving goals and objectives (Suartama, 2010 (Ervina et al., 2019; Yusuf, Umanailo, Putri, Ely, \& Darma, 2019). The effectiveness of learning can also be said as planned communication that results in changes in attitudes, skills, knowledge related to specific goals relating to the patterns of behaviour. The concept of effectiveness includes various factors from within to outside oneself. It cannot only be seen in terms of productivity but also can be seen in terms of one's perception or attitude. Besides, it can also be seen from the level of satisfaction someone achieved. For example, how a student learns using interactive media that makes his learning more effective.

\section{Articulate Storyline}

Articulate storyline update 2 is the latest version of software authorizing stand-alone e-learning authorizing. It is built to help users change the appearance of an object based on student interaction. The articulate storyline program supports features such as flash in making animation but has a simple interface like PowerPoint. The articulate storyline feature can be used as interactive multimedia because of its feasibility such as flash and interface and its simplicity as a PowerPoint. Besides, it has a characteristic, namely the existence of several menus such as the zoom button to enlarge the image, the question button to find out an explanation of the material, and navigation buttons such as next, back and submit under the screen that is automatically available in the media (Huang, Liang, Su, \& Chen, 2012).

Among the product specifications produced in this instructional media are articulate storyline-based instructional media that contains some content such as text, audio, images, animation, and evaluation tests. The animation is in the conversion of number systems, algebraic laws, and maps. This media is installed and applied to a Personal Computer (PC) or laptop that runs on Windows 7 or Windows 8 which has a flash player. The articulate storyline 2 was chosen because of its unique way of presenting interactive material in a quiz format. Apart from that, it can combine images and data, in the same way, to place material into power points. It is a great tool and also as an instructional designer that can be used easily because it has a simple appearance.

The articulate product allows users to present learning material effectively because it is equipped with an adjustable presentation pattern. Furthermore, it also allows interaction with other learning components based on learning design principles, such as the use of interactive video and audio, hotspots, rollover interactions, interaction tabs, and timelines. Examples of other learning designs are like lightboxes, markers, media animation and transitions, colours, zoom, FAQS, buttons, scenarios, simulations, tabular shapes to present data, and process diagrams. Some of the advantages of using the articulate storyline are that it is easy to use, accessible, makes interactive and effective assessments, and provides correct feedback to students. Previously, research on the articulate storyline had been investigated by others in the subject of human electronics and reproduction. This research was developed by researchers on the subject of Plant Breeding in SMKN in East Kalimantan Province, Indonesia. 
1

\section{Methods}

The study was conducted at State Vocational School, Loa Janan, Kutai Kertanegara Regency, Indonesia. The research used a mixed approach of qualitative and quantitative, with the research and development method referring to the Borg and Gall model. Based on Borg and Gall's theory, there are 10 stages of research and development process to produce multimedia products in Plant Breeding Lessons as follows:

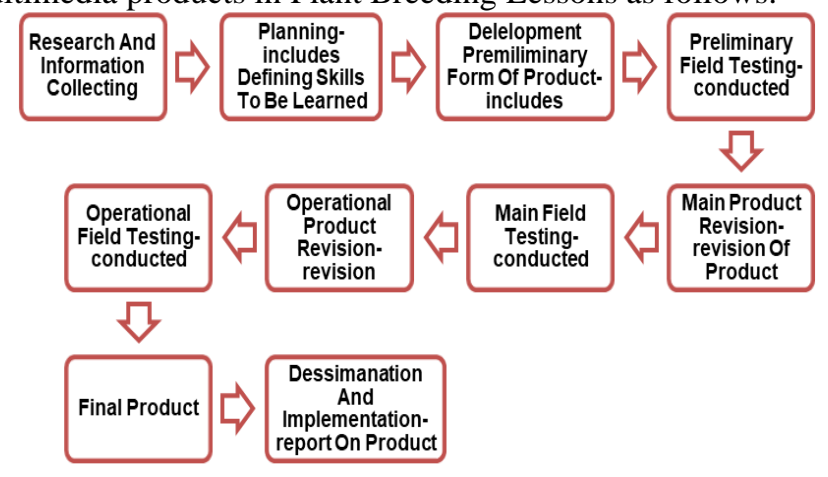

The compilation and development of computer-based instructional media on Plant Breeding subjects is carried out with the following steps: outlining a media program (OMP), a flowchart, and a storyboard. The next steps are gathering, programming and finishing instructional developed materials. Furthermore, researchers conducted several stages related to the design validation and improvement, product trials, data collection and analysis techniques. To analyze quantitative data from questionnaires distributed to the teacher of the subject, media experts, and students as users of products developed through articulate storyline 2, researchers used descriptive statistics. The data obtained from observations, interviews, and documentation were qualitatively analyzed (Novitasari et al., 2019; Thomas, Rajaraman, Zaidi, Linn, \& Rea, 2015; Umanailo, 2020c; Zumla et al., 2020). Furthermore, the interpretation and decision making was presented to see the quality of the product development by using a conversion rate of achievement using a 5 scale questionnaire as described in table 1 .

Table 1. Conversion Rate of Development Assessment

\begin{tabular}{ccc}
\hline Qualitative Assessment & Values & Interpretation \\
\hline Very Feasible & 5 & $81 \%-100 \%$ \\
Worthy & 4 & $61 \%-80 \%$ \\
Feasible Enough & 3 & $41 \%-60 \%$ \\
Enough & 2 & $21 \%-40 \%$ \\
Not Feasible & 1 & $20 \%$
\end{tabular}

\section{Results}

The results of this study are presented in response to the formulation of the problems at the core of this study in the following order.

Table 2. Conversion Rate of Feasibility Assessment for Articulate Storyline Product Development 2

\begin{tabular}{ccccc}
\hline Rating of Media Expert & Total & Average Value & $\%$ & Category \\
\hline Rating of Stage I Media Expert & 102 & 3.92 & 78 & Eligible \\
Rating of Phase II Media Expert & 124 & 4.76 & 95 & Very Proper \\
Rating of Phase III Media Expert & 129 & 4.96 & 96.60 & Very Proper \\
Rating of Phase IV Media Expert & 130 & 5.00 & 100 & Very Proper
\end{tabular}

Based on the quantitative calculations, the feasibility of developing the Articulate Storyline 2 product as a whole is divided into two aspects, namely the application aspect and the appearance of the products included in the category of "Very Eligible" included in stage 3 of $96.60 \%-100 \%$. The results of this calculation indicate that the assessment of instructional multimedia experts in plant breeding using articulate storyline 2 as a whole is considered very feasible. This means that this interactive multimedia can be maximally applied to instructional media.

\section{The Effectiveness of Instructional Media Using Articulate Storyline 2}

After the learning process by using articulate storyline 2 ends, then the instructional material being taught is tested (Derek \& Manginsela, 2016; Novitasari et al., 2019). The findings of student learning outcomes before and after following the learning process using articulate storyline 2 on

\section{Product Feasibility}

The results of the validation and evaluation of media experts in this field, starting from stage 1 to stage 4 , have produced interactive multimedia using the Articulate Storyline as shown in table 2 below. vegetative propagation topic for the students can be seen in table 3 . 
Table 3. Effectiveness of MultiMedia Articulate Storyline 2 In Learning Vegetative Plant Breeding

\begin{tabular}{lrlllll}
\hline & Using Articulate Storyline 2 & \multicolumn{3}{c}{ Using Articulate Storyline 2 } \\
\hline Students Not Complete & 9 & student & Students Not Complete & 3 & Student \\
Completed students & 5 & student & Completed students & 11 & Student \\
Total & 14 & student & Total & 14 & Student
\end{tabular}

Table 4. Changes in the Effectiveness of the Use of MultiMedia Articulate Storyline 2 in Learning Plant Breeding

\begin{tabular}{cccc}
\hline No & Change in Number & Total students & Total Value \\
\hline 1 & Increased & 11 & 938 \\
2 & Still & 1 & 73 \\
3 & Decreased & 2 & 140 \\
& Total & 14 & 1151
\end{tabular}

Student Average Grade $=\frac{\text { Total Student Grades }}{\text { Total students }}=\frac{1151}{14}=82.21$

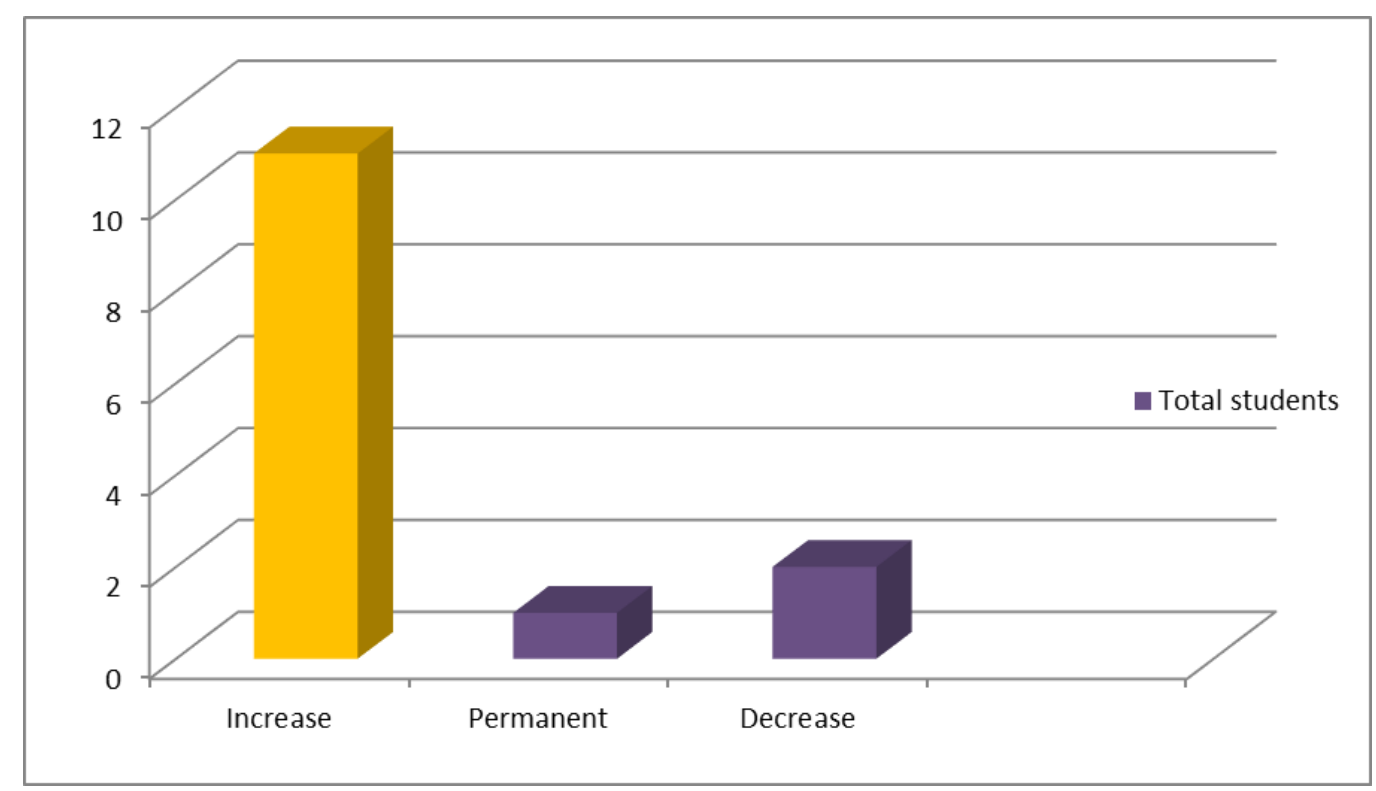

Diagram 1: Learning Effectiveness by Using MultiMedia Articulate Storyline 2

Table 4 and diagram 1 showed the changes and improvement in learning outcomes after the students used the multimedia Articulate Story 2 on the instructional material. of Plant Breeding 82.21. The increase in student learning outcomes has exceeded the teaching completeness criteria, 75 of the school. On the other word, it also shows the effectiveness of the use of the instructional media Articulate Storyline 2 on vegetative Plant Breeding topic at SMK Negeri Loa Janan

\section{Discussions}

The Feasibility of MultiMedia on Plant Breeding by Using Articulate Storyline 2

The results of the research development of instructional media using Articulate Storyline 2 show that this instructional media product has met and passed the feasibility test of the learning process of vegetative Plant Breeding material. It was obtained during the validation process of media experts and material experts

Based on the results of the validation of the media expert team, the determination of the feasibility of the instructional media product using Articulate Storyline 2 has passed the predetermined stage. The results of this feasibility are in line with the results of previous studies about the use of instructional media in learning (Silverberg et al., 2014; Sun \& Cheng, 2007; Thomas et al., 2015; Waskito, 2017). The assessment of the media is also carried out by media experts. Overall, the results of a feasibility assessment from a team of media experts who showed very high and very feasible can be seen in table 2 .

Before the feasibility assessment is determined, improvements and revisions to instructional media using Articulate Storyline 2 have been repeatedly carried out 
following the results of the assessment and advice of media experts, both from the aspect of application and media appearance. In conclusion, the results of this assessment of the Articulate Storyline 2 can be used in Plant Breeding learning. In general, the media was declared very feasible and very useful both for teachers and students.

\section{The effectiveness of instructional media by using Articulate Storyline 2}

The research on instructional media using Articulate Storyline 2 in Plant Breeding course is intended to make students more interested and motivated in learning. The media developed in this research are part of ICT because it is needed in innovative learning. Apart from that, it has interactions from various directions so the students can learn efficiently and easily understand the lesson and access information widely (Costello et al., 2014; Yuli Kwartolo, 2010).

It is an e-learning instructional media that was developed both off and on lines so that it becomes effective blended learning to improve and enhance the process and effectiveness of learning, and also increase the achievement of learning outcomes (Gunn, Lefoe, Graham, Left, \& Smith, 1999; Mohammad Yazdi, 2012; Phillips, Schumacher, \& Arif, 2016). Apart from that, the advantages of this instructional media are that it is very effective, interesting, and easy to use by users. The effectiveness of its use is evident with an increase in student learning outcomes with student average of 82.21 which exceeds the student minimum mastery criteria) of 75 set by the school.

This indicates that the development of the articulate storyline 2 media seem to be very effective in learning Plant Breeding. Based on data observations, it was found that teachers who use this developed media can direct students to integrate knowledge and skills and build student attitudes in the face of learning, so they can learn efficiently and effectively. Referring to previous researches, that the use of quality multimedia or interactive ICT in learning can effectively build the power of student learning because the students have positive perceptions and attitudes towards the use of interactive multimedia or ICT including several related aspects such as subjects, teachers, media, and a comfortable learning climate (Djibu et al., 2019; Farrukh et al., 2015). In short, qualified media and learning resources are those that can create meaningful learning experiences, facilitate the process of interaction among students and teachers, fellow students, and students and relevant science experts. It was also found that the articulate storyline 2 media succeeded in changing the learning atmosphere of students who had been passive to be active. Likewise, the role of the teacher in the classroom is no longer as a single source of learning but as a source assisted by interactive media to direct students to be more active in discussion and more dynamic.

The results of interviews with several school students showed that the majority of them were very fond of the development of this learning multimedia because it was very interesting and easily understood by students in responding to the subject matter.

\section{Conclusion}

After receiving an assessment from experts of media and information technology, and also the instructional material of plant breeding, it was found that the instructional media using articulate storyline 2 is suitable for use in Plant Breeding subjects at SMK Negeri Loa Janan, Kutai Kerta Negara Regency, Indonesia. The feasibility of using this media is the result of a long series of research activities, beginning from the problem analysis, data collection, product design, design validation, design revision, product testing, product revision, trial use, until mass production to produce a viable product used in learning. The results of this study prove that, in addition to helping students sharpen their understanding of the subject matter, this instructional media that use Articulate Storyline 2 is very interesting, easy to use, effective for improving learning outcomes, and helps students achieve and even exceed minimum standards of completeness criteria implemented by the school. are selling or renting with the motive of making a profit on the land. The land ownership in Namlea District is generally private land and customary land. The state guarantees ownership in the form of property rights, building rights, and usage rights, these three rights open up investment opportunities outside the agricultural sector. Land use is dominated by the housing sector due to population growth and urban development which causes the need for housing to increase

\section{References}

[1] Adiatma, D. S. (2014). Pengembangan Media CAI Berbasis Android Pada Mata Pelajaran Ilmu Pengetahuan Alam Materi Struktur dan Fungsi Jaringan Tumbuhan Untuk Siswa Kelas VIII SMPN 1 Tembelang Jombang. Jurnal Mahasiswa Teknologi Pendidikan.

[2] Apriyanto, M., \& Umanailo, M. C. B. (2019). Decrease Polyphenols , Ethanol, Lactic Acid, and Acetic Acid during Fermentation with Addition of Cocoa Beans Innoculum. International Journal Of Scientific \& Technology Research, 8(10).

[3] Bodolica, V., \& Spraggon, M. (2008). Work experiences of Moldovan women in Italy: bearing the double identity strangeness. Equal Opportunities International. https://doi.org/10.1108/026101508108972 91

[4] Chen, X. P., Cui, Z. L., Vitousek, P. M., Cassman, K. G., Matson, P. A., Bai, J. S., ... Zhang, F. S. (2011). Integrated soil- 
crop system management for food security. Proceedings of the National Academy of Sciences of the United States of America. https://doi.org/10.1073/pnas.1101419108

[5] Costello, E., Corcoran, M., Barnett, J. S., Birkmeier, M., Cohn, R., Ekmekci, O., ... Walker, B. (2014). Information and communication technology to facilitate learning for students in the health professions: Current uses, gaps, and future directions. Journal of Asynchronous Learning Network. https://doi.org/10.24059/olj.v18i4.512

[6] Derek, R. R., \& Manginsela, R. R. D. E. P. B. O. L. S. (2016). Strategi Hidup Masyarakat Petani Di Kelurahan Pandu, Kecamatan Bunaken, Kota Manado. AgriSosioekonomi, 12(2A), 91-106.

[7] Djibu, R., Shofwan, I., \& Umanailo, M. C. B. (2019). Development of Andragogical Learning Model to Improve Life Skill for Teenagers Who Drop Out of School in Gorontalo City. International Journal Of Scientific \& Technology Research Volume, 8(10).

[8] Ervina, A., Zulmi, D., Ariesta, R., Aridawarni, Y., Aminah, A., \& Umanailo, M. C. B. (2019). The Relationship of Patterns Use of Time and Income Family with Juvenile Delinquency in Junior High School Students at Lebak Distric. International Journal Of Scientific \& Technology Research Volume, 8(10).

[9] Farrukh, M., Butt, S., \& Mansori, S. M. (2015). Innovation capability: The role of Islamic work ethics. Journal of Asian Business Strategy.

[10] Gunn, C., Lefoe, G., Graham, A., Left, P., \& Smith, C. (1999). Getting IT Together: A Cooperative Model for Staff Development. Responding to Diversity, Proceedings of the 16th Annual Conference of the Australian Society for Computers in Learning in Tertiary Education.

[11] Hoang, V. T., Gautret, P., Memish, Z. A., \& Al-Tawfiq, J. A. (2020). Hajj and
Umrah Mass Gatherings and COVID-19 Infection. Current Tropical Medicine Reports, 7(4), 133-140. https://doi.org/10.1007/s40475-02000218-X

[12] Huang, Y. M., Liang, T. H., Su, Y. N., \& Chen, N. S. (2012). Empowering personalized learning with an interactive ebook learning system for elementary school students. Educational Technology Research and Development. https://doi.org/10.1007/s11423-012-92376

[13] Huda, M., Haron, Z., Ripin, M. N., Hehsan, A., \& Yaacob, A. B. C. (2017). Exploring innovative learning environment (ILE): Big data era. International Journal of Applied Engineering Research.

[14] Jannah, M., Widohardhono, R., Fatimah, F., Dewi, D. K., \& Umanailo, M. C. B. (2019). Managing cognitive anxiety through expressive writing in studentathletes. International Journal of Scientific and Technology Research, 8(10).

[15] Jannah, Miftakhul， Widohardhono， R., Fatimah, F., Dewi, D. K., \& Umanailo, M. C. B. (2019). Managing Cognitive Anxiety through Expressive Writing in StudentAthletes. International Journal Of Scientific \& Technology Research Volume, 8(10).

[16] Kimin, K., Rahman, A., Conang, A., \& Umanailo, M. C. B. (2020). Analysis of horizontal sumbu wind tines using three blades and diameters of 12 meter kinds on wind speed in Barat-Maluku Seram Region. Proceedings of the International Conference on Industrial Engineering and Operations Management, 0(March), 25832587.

[17] Kirk, Emerson and Nabatchi, T. (2015). Collaborative Governance Regimes (Public Man; B. A. Radin, Ed.). Washington, DC: Georgetown University Press.

[18] Malmia, W., Makatita, S. H., Lisaholit, S., Azwan, A., Magfirah, I., Tinggapi, H., \& Umanailo, M. C. B. (2019). Problem- 
based learning as an effort to improve student learning outcomes. International Journal of Scientific and Technology Research, 8(9).

[19] Mangesa, R., Kasmawati, K., Darma, D., Lisaholit, S., Setiaji, A. B., \& Umanailo, M. C. B. (2019). Identification and Testing Resistance Against Bacteria Isolated Mercury from Gold Mining In Gogorea Buru. International Journal Of Scientific \& Technology Research Volume, 8(10).

[20] Mohammad Yazdi. (2012). E-learning sebagai Media Pembelajaran Interaktif Berbasis teknologi Informasi. Jurnal Ilmua Foristek.

[21] Muharlisiani, L. T., Noerhartati, E., Karwanto, K., Chamidah, D., Wisnujati, N. S., Soewardini, H. M. D., ... Umanailo, M. C. B. (2019). Public Relations Management through Management by Objective. International Journal Of Scientific \& Technology Research, 8(10).

[22] Muhasidah, M., Nasrullah, N., Yusuf, M. M., Jaya, N., Laubo, N., Angriani, S., ... Farida, N. N. (2019). Healthy Food with Children Learning Achievements at Makassar City Elementary School. International Journal of Scientific \& Technology Research Volume, 8(10), 1875-1882.

[23] Nawawi, M., Ali, A., Irawan, B., Ahmad, B., Mukramin, S., Marsuki, N. R., ... Kaya, I. R. G. (2020). The village kalesang program as a poverty alleviation community. International Journal of Scientific and Technology Research, 9(3), 3103-3107.

[24] Novitasari, R., Usanti, T. P., Adiansha, A. A., Soesantari, T., Said, M. F., Hanapi, H., ... Umanailo, M. C. B. (2019). The Existence of Waranggana in Tayub Ritual. International Journal of Scientific \& Technology Research Volume, 8(10).

[25] Phillips, J. A., Schumacher, C., \& Arif, S. (2016). Time spent, workload, and student and faculty perceptions in a blended learning environment. American Journal of
Pharmaceutical

Education.

https://doi.org/10.5688/ajpe806102

[26] Rachman, S., Hamiru, H., Umanailo, M. C. B., Yulismayanti, Y., \& Harziko, H. (2019). Semiotic Analysis of Indigenous Fashion in The Island of Buru. International Journal of Scientific \& Technology Research, 8(8), 1515-1519.

[27] Rahmat, A., Gs, A. D., Djafri, N., Shofwan, I., \& Umanailo, M. C. B. (2019). The Influence of Family Leadership towards Adolescent Social Values in the City of Gorontalo. International Journal Of Scientific \& Technology Research, 8(10).

[28] Romlah, S. N., Pratiwi, R. D., Indah, F. P. S., \& Umanailo, M. C. B. (2020). Qualitative study factors triggering gay characteristics in gay groups in Palmerah District West Jakarta. Proceedings of the International Conference on Industrial Engineering and Operations Management.

[29] Rumaolat, W., Dusra, E., Tunny, I. S., Malisngorar, M. S. J., Cahyawati, S., \& Umanailo, M. C. B. (2019). Relationship Diet and Regulate Blood Sugar in the Elderly with DM Type Ii in Waimital Village , Kairatu District , West Seram Regency. International Journal Of Scientific \& Technology Research, 8(10).

[30] Rumaolat, W., Lihi, M., Hamka, H., \& Umanailo, M. C. B. (2019). Factors Associated With Mother in Doing Diarrhea Prevention Efforts in Toddler Village Iha Work Area Community Health Center Amahai. International Journal Of Scientific \& Technology Research Volume, 8(10).

[31] Salampessy, H., Tuhelelu, A., Wahyudi, I., \& Umanailo, M. C. B. (2020). Banking servqual analysis of customer satisfaction (case study at Ambon branch BRI bank in Ambon City). Proceedings of the International Conference on Industrial Engineering and Operations Management, 0(March), 2575-2582.

[32] Silverberg, L. J., Tierney, J., \& Bodek, M. J. (2014). Use of Doceri software for iPad in online delivery of chemistry content. 
Journal of Chemical Education. https://doi.org/10.1021/ed4009057

[33] Siswanto, S., Supriyanto, A. S., Ni'mah, U., Asnawi, N., \& Wekke, I. S. (2019). Does a workload influence the performance of bank employees? Management Science Letters. https://doi.org/10.5267/j.msl.2019.2.007

[34] Suartama, I. K. (2010). Kualitas Pembelajaran Pada Mata Kuliah Media. Jurnal Pendidikan Dan Pengajaran.

[35] Sun, P. C., \& Cheng, H. K. (2007). The design of instructional multimedia in eLearning: A Media Richness Theory-based approach. Computers and Education. https://doi.org/10.1016/j.compedu.2005.11 .016

[36] Tahir, S. Z. A. Bin, \& Umanailo, M. C. B. (2019). Consumption Culture of Namlea Communities. Proceedings of the International Conference on Industrial Engineering and Operations Management Riyadh, Saudi Arabia, 974-978. Riyadh, Saudi Arabia: IEOM Society International.

[37] Thomas, J., Rajaraman, N., Zaidi, N., Linn, A., \& Rea, P. (2015). Integrated Anatomy E-Tutorial Designed By Medical Students, Combining Articulate Storyline 2 With Images From Anatomy. Tv. EDULEARN15 Conference.

[38] Umanailo, M. C. B. (2020a). Dominance of economic capital. International Journal of Scientific and Technology Research.

[39] Umanailo, M. C. B. (2020b). Dominance of Economic Capital. International Journal Of Scientific \& Technology Research Volume, 9(01), 1-4.

[40] Umanailo, M. C. B. (2020c). The energy in the context of social. Proceedings of the International Conference on Industrial Engineering and Operations Management, 0(March), 2503-2508.

[41] Umanailo, M. C. B., Yulisvestra, M., Oki, K. K., Mulyasari, W., \& Ridwan, R. (2019). The Thought of Emile Durkheim in the Contestation of Development in Indonesia. International Journal of
Scientific \& Technology Research, 8(8), 1881-1885.

[42] Waskito, D. (2017). Media Pembelajaran Interaktif Matematika Bagi Sekolah Dasar Kelas 6 Berbasis Multimedia. Speed Sentra Penelitian Engineering Dan Edukasi.

[43] Xu, X., Polley, H. W., Hofmockel, K., \& Wilsey, B. J. (2017). Species composition but not diversity explains recovery from the 2011 drought in Texas grasslands. Ecosphere. https://doi.org/10.1002/ecs2.1704

[44] Yuli Kwartolo. (2010). Teknologi Informasi dan Komunikasi dalam Proses Pembelajaran. Jurnal Pendidikan Penabur.

[45] Yusuf, S., Umanailo, M. C. B., Putri, R. N., Ely, D. Q. M., \& Darma, D. (2019). Village Institution Relations in the Utilization of Village Funds in Namlea District. International Journal Of Scientific \& Technology Research, 8(8).

[46] Zhao, M., \& Hannum, E. (2019). Stark Choices: Work-Family Tradeoffs among Migrant Women and Men in Urban China. Chinese Sociological Review. https://doi.org/10.1080/21620555.2019.16 35879

[47] Zumla, A., Azhar, E. I., Alqahtani, S., Shafi, S., \& Memish, Z. A. (2020). COVID-19 and the scaled-down 2020 Hajj Pilgrimage-Decisive, logical and prudent decision making by Saudi authorities overcomes pre-Hajj public health concerns. International Journal of Infectious Diseases, 99, 34-36. https://doi.org/10.1016/j.ijid.2020.08.006 